\title{
The Performance of English Teaching at University and Its Influencing Factors
}

\author{
Xiaohui Xie ${ }^{1, a}$, Weilun Huang ${ }^{1, b, *}$ \\ ${ }^{1}$ Wenzhou Business College, Zhejiang, China \\ a824477922@qq.com, bhuangwl@wzbc.edu.cn \\ ${ }^{*}$ Corresponding author
}

Keywords: English Teaching, University, English learning mode.

\begin{abstract}
This paper explores the performance of English teaching at university (ETU) in China and its influencing factors based on literature review and questionnaire analysis. The results of the questionnaires showed that the ETU performance in China could be promoted, which could be proved on the average scores of CET-4, CET-6, TOEFL, and IELTS, as well as respondent's self-awareness of English communication. This paper found that English learner's characteristics (ELC), English teaching environment in school (ETS), English teaching environment in the family (ETF) and respondents' variables are the influence factors on the performance of ETU. The individual variables of respondents are their gender (GEN), residence (RES), education (EDU), foreign experience (FE). In order to improve the performance of ETU, the suggestions of the government could establish a flexible and innovative English learning mode; encourage the bilingual policies and education system; improve the bilingual services at cultural and educational centers; promote the internationalization of education system. The universities could provide more courses, competitions; and seminars related to English; establish the platform with the integrated English learning and translation resources, and implement the individuation learning strategies. This paper also suggests that families should create a bilingual service environment.
\end{abstract}

\section{Introduction}

Nowadays, with the rapid economic development, more and more governments and enterprises need to communicate internationally, so they need a large number of highly qualified English workers, and universities are the necessary institutions for the training of English workers, and urgently required to improve the performance of English teaching at university (ETU). However, few papers are discussing the performance of ETU and its influencing factors. Therefore, the purpose of this paper is to use literature review and questionnaire analysis to understand the performance of ETU and to explore the influencing factors that English learner's characteristics (ELC), English teaching environment in school (ETS), English teaching environment in family (ETF), and individual variables of English learners. This paper provides suggestions for English learners, universities, families to promote the performance of ETU. Literature review shows that the number of Chinese graduates who major in English could find a job is the third among all majors. Shenzhen is the most significant requirement region of the graduates who major in English, their average monthly salary is around RMB 6,580, and after working for 5-10 years, their average monthly salary could be up to RMB 12,890.

The review of the literature shows that the performance of ETU should be an essential research topic. However, less literature discussed the influence of ETF, ETS, and ELC on the performance of ETU. Therefore, the purpose of this paper is to explore the performance of ETU and its influencing factors. This paper sorts out the existing literature in China and finds that the paper study the target of ETU started in 1979, and there are 3,412 papers have been published on here now (June 15, 2019). However, this paper focus on the performance of ETU which are studied find the papers published after 2005, and there are 111 papers on here, on June 15, 2019. The above studies focus on the research field which is the industry guidance of English teaching and the emphasis of contents the 
influence that cross-cultural teaching, flipped classroom, Internet + , and humanities training on the performance on ETU. For example, Chen and Yang (2019) use the technology of big data to explore the impact on the performance of ETU by the ecological environment on English teaching.

The variables on the performance of ETU are respondents' highest scores of College English Test Band 4 (CET-4), College English Test Band 6 (CET-6), Test of English as a Foreign Language (TOEFL) and International English Language Testing System (IELTS), and the self-awareness of English communication (SAEC). For example, Mao (2015) finds the influence of students' English learning motivation, which are integrative motivation and instrumental motivation is significant on their scores of IELTS. Liu, Li, and Liu (2018) used the binary logistic model to prove that college students' performance-approach goal and performance-avoidance goal have significant positive and negative impacts on their CET-4 scores.

From the review of Literature, there are many influencing factors on the performance of ETU. According to the sociology of teaching, this paper chose ELC, ETS, and ETF as the influencing factors on the performance of ETU. Ministry of Education of the People's Republic of China implemented the teaching requirements for college English courses in 2007, which aimed to improve the performance of ETU. For example, Wang (2012) found that the influencing factors on the performance of ETU are students' learning strategies, teachers' professional quality and teaching ideas, teaching equipment, and teaching environment.

This paper defines the variables regarding ELC as English learner motivations, interests, and the participation of English extracurricular paid courses, based on previous researches. For example, Zhang (2016) found there are definite relations between English learner motivations and strategies, and between English learner performance and strategies. Therefore, English learner has a stronger motivation, would have better performance as Shao (2016) believed that the influencing factors on the performance of ETU are students' age, gender, intelligence, attitude, motivation, learning style, and study autonomy.

Based on previous studies, this paper defines the variables of ETF as families' income, parents' education, the percentage of English learning expenses in family income, and tutors hiring. Kaori and Motonori (1999) believed that the performance of ETU is better with families to have a higher income. Zhang and Zou (2006) argued that families' income, parents' education, and parent's socioeconomic status have significant impacts on students' performance of English teaching at the compulsory education stage in Shanghai.

According to the review of literature, the ETS variables in this paper include students starting age of English teaching, the characteristics of universities, the number of students in a class, teaching methods, the educational experience and evaluations of English teachers, courses taught in English, and tuition fees. Wang (2014) believed that the students getting English teaching are earlier; their performance on ETU is better.

In order to further understand the performance of ETU and its influencing factors. This paper also discusses the impacts of students individual variables such as their gender (GEN), residence (RES), education (EDU), foreign experience (FE) on the performance of ETU and its influencing factors. Shao (2017) believed that learning attitudes, motivations, and concentration degrees of female students are better than male students, so their performance of ETU is better.

This paper contains three parts, including the introduction. The second part analyses the results of the questionnaires, and the third part is the conclusion and suggestion.

\section{Analysis of questionnaires}

From June 15 to June 23, 2019, Chinese online questionnaire was conducted. There were 629 copies have been filled in and collected. All respondents were English learners in universities. The statistical results of respondents individual variables were: (1).GEN (\%): Respondents are male (36.6\%), or female (63.4\%). (2). RES (\%): Respondents live in rural area (42.9\%), or urban area (57.0\%). (3). EDU (\%): Respondents' educations are below undergraduate $(49.3 \%)$, or above undergraduate (50.7\%). (4). FE (\%): Respondents have FE(43.7\%), or no FE (56.3\%). 
The statistical results of the variable on the ETU's performances are: $11.0 \%, 27.5 \%, 39.4 \%$, and $38.0 \%$ of the respondents did not take examinations of (1) CET-4, (2) CET-6, (3) TOEFL and (4) IELTS. The average scores (standard deviation) of (1) CET-4, (2) CET-6, (3) TOEFL, and (4) IELTS of respondents who have taken these examinations are 503.9 (170.6), 502.3 (232.2), 78.1 (41.9), and 6.0 (3.0). Respondents' average evaluation (standard deviation) of SAEC is 3.3 (1.1).

The narrative statistics results of the influencing factors on the performance of ETU are as follows: (1) More than $70 \%$ of the respondents approved that their significant influencing factors (approval proportion) were ETS (87.0\%), ETF (73.4\%), and ELC (73.1\%). (2) The result on the variables of ELC (\%) are the English learner motivations (80.1\%), interests $(79.5 \%)$, and the participation of English extracurricular paid courses $(66.7 \%)$. (3) The result on the variables of ETF (\%) is the families' income $(86.0 \%)$, tutors hiring $(85.2 \%)$, the percentage of English learning expenses in family income $(84.8 \%)$, parents' education $(76.6 \%)$. (4) The result of the variables of ETS (\%) is the educational experience and evaluations of English teachers (84.7\%), students starting age of English teaching (79.8\%), the characteristics of universities (79.8\%), courses taught in English (77.9\%), the number of students in a class $(69.3 \%)$, teaching methods $(60.2 \%)$, and tuition fees $(55.2 \%)$.

The variance analysis between the performance of ETU and its influencing factors are shown in Table 1. From Table 1, it could be seen ELC was the significant factors on the performance of CET-4, TOEFL, IELTS, and SAEC; ETS was the significant factors on the performance of CET-4, TOEFL, and IELTS. ETF was the significant factors on the performance of CET-4, CET-6, TOEFL, IELTS, and SAEC.

Table 1. Variation Analysis between the performance of ETU and its influencing factors.

\begin{tabular}{|c|c|c|c|c|c|c|}
\hline & & \multicolumn{5}{|c|}{ The performance of ETU in China } \\
\hline & & CET-4 & CET-6 & TOEFL & IELTS & SAEC \\
\hline \multirow{3}{*}{$\begin{array}{l}\text { Its } \\
\text { Influen } \\
\text { ce } \\
\text { Factors }\end{array}$} & ELC & $1.5^{*}$ & 1.3 & $2.3 * * *$ & $1.6^{*}$ & $2.9^{* * *}$ \\
\hline & ETS & $2.0^{* *}$ & 1.6 & $2.1 * *$ & $1.7^{*}$ & 1.2 \\
\hline & ETF & $707.2 * * *$ & $9.0 * * *$ & $8.2 * * *$ & $6.1 * * *$ & $2.0 *$ \\
\hline
\end{tabular}

Note: $* \mathrm{p}<0.05, * * \mathrm{p}<0.01, * * * \mathrm{p}<0.001$.

In order to further understand the results of the questionnaires, this paper discusses the impact of GEN, RES, EDU, and FE on the performance of ETU and its influencing factors. The results of respondents sample t-test of individual variables on ETU's performance and its influencing factors are shown in Table 2. From table 2, Respondents' RES had a significant influence on the performance of CET-4, CET-6, and TOEFL; Respondents' EDU had a significant influence on the performance of CET-4, CET-6, TOEFL, and IELTS; Respondents' FE had a significant influence on the performance of CET-4, CET-6, and IELTS. The CET-4, CET-6, and TOEFL scores of university students living in urban area were higher than those in a rural area with 11.6, 74.8, and 13.9. The CET-4, CET-6, TOEFL, and IELTS scores of university students whose education were above undergraduate were higher than those below undergraduate with 3.0, 70.6, 25.9, and 2.1. The CET-4, CET-6, and IELTS scores of university students who had FE were higher than those who had no FE with 59.0, 47.9, and 0.6 .

Table 2. The results of respondents sample t-test of individual variables on ETU's performance and its influencing factors.

\begin{tabular}{cccccc}
\hline & GEN & RES & EDU & FE \\
\cline { 2 - 5 } & $\mathrm{F}(\mathrm{T})$ & $\mathrm{F}(\mathrm{T})$ & $\mathrm{F}(\mathrm{T})$ & $\mathrm{F}(\mathrm{T})$ \\
\hline $\begin{array}{c}\text { The } \\
\text { performance } \\
\text { of ETU in } \\
\text { China }\end{array}$ & CET-4 & $1.9(-1.2)$ & $13.4^{* * *}(-0.8)$ & $13.8^{* * *}\left(0.2^{* * *}\right)$ & $17.9^{* * *}\left(4.6^{* * *}\right)$ \\
\cline { 2 - 5 } & CET-6 & $2.2(0.7)$ & $57.3^{* * *}\left(4.1^{* * *}\right)$ & $11.9^{* * *}\left(3.9^{* * *}\right)$ & $21.6^{* * *}\left(2.6^{* *}\right)$ \\
\hline
\end{tabular}




\begin{tabular}{lccccc}
\hline & TOEFL & $2.1(-0.8)$ & $10.9 * * *\left(4.2^{* * *}\right)$ & $36.9 * * *\left(8.2^{* * *}\right)$ & $0.9(3.3 * * *)$ \\
\cline { 2 - 5 } & IELTS & $0.1(0.5)$ & $3.0(1.7)$ & $72.3^{* * *}\left(9.0^{* * *}\right)$ & $22.6^{* * *}(2.7 * *)$ \\
\cline { 2 - 5 } & SAEC & $0.1(-0.2)$ & $0.3(-2.7)$ & $13.5^{* * *}(0.4)$ & $2.7(0.9)$ \\
\hline \multirow{2}{*}{$\begin{array}{c}\text { Its influence } \\
\text { factor }\end{array}$} & ELC & $0.3\left(-2.8^{* *}\right)$ & $0.3\left(0.5^{* *}\right)$ & $6.9 * *\left(-2.2^{*}\right)$ & $0.0(1.3)$ \\
\cline { 2 - 5 } & ETS & $0.1(-0.7)$ & $3.1 * *\left(-2.9^{* *}\right)$ & $2.9^{* * *}\left(-3.5^{* * *}\right)$ & $0.6(-0.7)$ \\
\hline
\end{tabular}

Note: ${ }^{*} \mathrm{p}<0.05,{ }^{* *} \mathrm{p}<0.01,{ }^{* * *} \mathrm{p}<0.001$.

Respondent' EDU have significant effects on ELC and ETS. The respondents whose education were above undergraduate had the more approval degrees of ELC and ETS than those who were below undergraduate.

Respondents' FE has significant effects on ELC and ETF. The respondents who had FE had more approval degrees of ELC and ETF than those who had no FC.

Based on the above discussion, this paper suggests that:

1. In order to improve the students' performance on ETU, the government should establish a flexible and innovative English learning mode for students and promote bilingual policies. Besides, universities should provide more courses related to English. This paper found that the average scores of CET-4, CET-6, TOEFL, IELTS, and SAEC of respondents who have taken these examinations could be promoted. As the government could assist in the full implementation of bilingual schools, and relax the relevant enrollment regulations for the flexible and innovative English learning environment and explore the global vision of students. The universities could provide the study courses of CET-4, CET-6, TOEFL, IELTS, and English communication for students.

2. The government should fully activate the bilingual education system and train bilingual talents for the world. Moreover, the universities should establish a platform with integrated English learning and translation resources. According to the survey results, in terms of the ETS variables, $77.9 \%$ agreed the course taught in English were conducive to improve the English performance of ETU; $79.8 \%$ believed that the students receive the courses related to English earlier, their performance of ETU is better as the government should implement full English teaching on English courses in primary and secondary schools. Moreover, the universities could establish the English learning platform, which should include the English resources of translation, online learning, online proficiency testing, and video channels.

3. For the improvement of student's motivations and interests, the government should increase the bilingual services at cultural and educational centers, and universities hold competitions and seminars related to English regularly. According to the results of this study, ELC (a students' learning motivation, and interest) and the performance of ETC had a significant positive correlation, so the universities could provide the courses related with English dramas and films to improve students' English learning interest. The government could encourage museums, libraries, and other cultural centers to provide bilingual services.

4. The family should create a bilingual service environment for students to promote the performance of ETU. According to the results of this paper, ETF was the significant factors on the performance of CET-4, CET-6, TOEFL, IELTS, and SAEC. Therefore, families should allocate part of the income on the courses of English learning and use the neighborhood English resources.

5. The government could promote the internationalization of education system. Moreover, Universities should implement differentiated learning strategies based on learner's variables. According to the survey results, learner' variables would partially significant affect the performance of ETU and its influencing factors. Therefore, this paper suggests that universities should use more effective learning strategies to improve the performance of ETU as the government and universities should strengthen international exchange opportunities of English education, which included 
international study partners, international travel of education, according to the individual variables of students.

\section{Conclusion}

Nowadays, governments and enterprises need more highly qualified English workers, and the universities are an essential institution of English teaching, so this paper focuses on the performance of ETU and its influencing factors, then further discuss the impact of students' variables on them.

According to the statistical results of the questionnaire, it is found that: (1) from the average scores of CET-4, CET-6, TOEFL and IELTS for the universities students in China, this paper found they could be improved by English teaching policies and strategies of government, universities, and families. (2) ELC, ETS, and ETF are significant influencing factors of the performance on ETU. The government, universities, and families could consider the English teaching policies and strategies to improve the students' motivation, interest, and strategies. (3) Student's GEN, RES, EDU, and FE have a significant influence on the performance of ETU and its influencing factors. The governments, universities, and families should develop differentiated English teaching policies and strategies by individual variables separation.

Based on the above discussion, the suggestions of the government are to establish a flexible and innovative English learning mode; to promote the bilingual policies and education system; to improve the bilingual services at cultural and educational centers; to promote the internationalization of education system. The suggestions of universities should provide more courses, competitions, and seminars related to English; establish the platform with the integrated English learning and translation resources, and implement the differentiated learning strategies. The suggestion of families should create a bilingual service environment.

The future research direction of this paper is to study more influencing factors on the performance of ETU, as the education method of the flipped classroom, Yan (2018) emphasized the feasibility of flipped classroom and the performance of ETU. Ma and Lei (2018) found that the flipped classroom based on MOOC (Massive Open Online Courses) can improve students' self-learning ability and enhance the teaching quality of teachers, and then improve the performance of ETU.

\section{References}

[1] Chen W., and Yang Y. A., Study on the construction of ecological environment of college English education in big data environment, Journal of North University for Nationalities, vol. 02. pp. 167-171, 2019.

[2] Mao J., An empirical study on the effect of integrative motivation and instrumental motivation on IELTS scores, Journal of Lanzhou Institute of Education, vol. 31(04), pp. 112-113, 2015.

[3] Liu Q., Li Q., and Liu Z., Reliability and validity of Chinese version of achievement goal questionnaire and its application in open college English teaching, Journal of Clinical Psychology, vol. 26(05), pp. 922-926, 2018.

[4] Shao Y., A study on factors affecting English learning and college English teaching effectiveness, English square, vol. 11, pp. 88-90, 2017.

[5] Wong X., An analysis of the factors affecting college English teachers' teaching effectiveness, Overseas English, vol. 17, pp. 79-80, 2012.

[6] Zhang W., Wang J., Li B., Hu G., and Wu Y. A study on the correlation among English learning motivation, strategy, and achievement of non-English majors, Modern communication, vol. 19, pp. 19-20, 2016.

[7] Okano K., and Tsuchiya M., Education in contemporary Japan, Cambridge: Cambridge University Press, vol. 54, 1999. 
[8] Zhang S., and Zou W., A study on the relationship between comprehensive factors of home school students and the effect of basic English education, Shanghai, Education Research, vol. 1, pp. 51-53, 2006.

[9] Wang Y., The differences between family English education and school English education for Chinese children, Education and Teaching Forum, vol. 34, pp. 8-9, 2014.

[10] Shao Y., A study on factors affecting English learning and college English teaching effectiveness, English Square, vol. 11, pp. 88-90, 2017.

[11] Yan Z., A study on the MOOC-based college English rollover classroom teaching model and its effectiveness, Modernization of education, vol. 5(35), pp. 291-292+323, 2018.

[12] Ma C., Thunder hard, A study on the effect of college English rollover class based on MOOC, New Curriculum Research (mid-issue), vol. 10, pp. 95-97, 2018. 